\title{
Efficacy of Different Herbicides on Weed dynamics and Yield Attributes in Kharif Blackgram [Vigna mungo (L.)]
}

\author{
M. Susmitha*, U. Vijaya Bhaskar Reddy, P.V. Ramesh Babu and M. Srinivasa Reddy \\ Department of Agronomy, Agricultural College, Mahanandi-518 502, Andhra Pradesh, India \\ *Corresponding author:
}

\section{Keywords}

Blackgram,

Herbicides, Hand weeding, Weed control efficiency, Yieldattributes and Yield

Article Info

Accepted:

15 May 2019

Available Online:

10 June 2019
A field experiment was conducted at College Farm, Agricultural College, Mahanandi on sandy loam soils to know the efficacy of different herbicides in kharif blackgram [Vigna mungo (L.)]. The field experiment was laid out in a Randomised Block Design with nine treatments in three replications. Among these treatments, the lower weed dry weight, high weed control efficiency, yield attributes, maximum seed yield $\left(1995 \mathrm{~kg} \mathrm{ha}^{-1}\right)$, haulm yield $\left(2687 \mathrm{~kg} \mathrm{ha}^{-1}\right)$ and harvest index $(42.62 \%)$ were recorded under hand weeding at 20 and 40 DAS, which was statistically similar with pendimethalin $30 \% \mathrm{EC}+$ imazethapyr $2 \%$ EC @ $1.0 \mathrm{~kg}$ a.i. $\mathrm{ha}^{-1}$ as pre-emergence application + sodium acifluorfen $16.5 \%$ SL+ clodinafop-propargyl 8\% EC @ $165+80 \mathrm{~g}$ a.i. ha $^{-1}$ at 2-3 leaf stage of weeds.

\section{Introduction}

Blackgram [Vigna mungo (L.)] is an important remunarative legume crop cultivated worldwide in tropical and subtropical regions and is valued for its high protein in seeds. Pulses occupy important position in Indian economy next to cereals and oilseeds with an area of $3.47 \mathrm{M}$ ha during kharif season, producing $2.176 \mathrm{M}$ tonnes with a productivity of $632 \mathrm{~kg} \mathrm{ha}^{-1}$. In rabi, it occupies $1.0 \mathrm{M}$ ha area, producing $0.655 \mathrm{M}$ tonnes with a productivity of $650 \mathrm{~kg} \mathrm{ha}^{-1}$ (2016-17) (www.Indiastat.com). In Andhra Pradesh blackgram during kharif season occupies $0.06 \mathrm{M}$ ha area, producing $0.049 \mathrm{M}$ tonnes ha ${ }^{-1}$ with productivity of $819 \mathrm{~kg} \mathrm{ha}^{-1}$ (WWW.apagrinet.gov.in, 2016-17). Control of weeds during critical period of crop weed competition is very important to avoid severe yield losses. The manual method of weed control, no doubt, accomplish the job effectively but they are tedious, time taking and expensive. Moreover, many times labour is not available at the critical period of weed removal. Recent trend of herbicide use is to find out an alternative and effective weed management by using low dose high efficiency herbicides which will not only reduce the total volume of herbicide per unit 
area but also the application becomes easier and economical to the farmer besides being eco-friendly.

\section{Materials and Methods}

A field experiment was conducted to study the "Efficacy of different herbicides in kharif blackgram [Vigna mungo (L.)]" during kharif season of 2018 on sandy loam soils of College Farm, at Agricultural College, Mahanandi, Andhra Pradesh. The rainfall received during the crop growth period was very meagre i.e. $163.5 \mathrm{~mm}$. The soil of the experimental site was neutral $\mathrm{pH}$ (7.41), medium in organic carbon (0.63) and $\mathrm{N}(287$ $\left.\mathrm{kg} \mathrm{ha}^{-1}\right)$, low in $\mathrm{P}_{2} \mathrm{O}_{5}\left(47 \mathrm{~kg} \mathrm{ha}^{-1}\right)$ and high in $\mathrm{K}_{2} \mathrm{O}\left(382 \mathrm{~kg} \mathrm{ha}^{-1}\right)$. The field experiment was laid out in a Randomised Block Design with nine treatments in three replications. The treatments consisting of pendimethalin 30\% EC @ $1.0 \mathrm{~kg}$ a.i. $\mathrm{ha}^{-1}$ as pre-emergence application $\left(\mathrm{W}_{1}\right)$, pendimethalin $30 \% \mathrm{EC}+$ imazethapyr 2\% EC @ $1.0 \mathrm{~kg}$ a.i. ha ${ }^{-1}$ as preemergence application $\left(\mathrm{W}_{2}\right)$, pendimethalin $30 \%$ EC@1.0 kg a.i. ha ${ }^{-1}$ as pre-emergence application + sodium acifluorfen 16.5\% SL + clodinafop-propargyl 8\% EC @ $165+80 \mathrm{~g}$ a.i. ha ${ }^{-1}$ at $2-3$ leaf stage of weeds $\left(\mathrm{W}_{3}\right)$, pendimethalin $30 \% \mathrm{EC}+$ imazethapyr $2 \% \mathrm{EC}$ @ $\quad 1.0 \mathrm{~kg}$ a.i. $\mathrm{ha}^{-1}$ as pre-emergence application + sodium acifluorfen 16.5\% SL+ clodinafop-propargyl 8\% EC @ $165+80 \mathrm{~g}$ a.i.ha ${ }^{-1}$ at 2-3 leaf stage of weeds $\left(\mathrm{W}_{4}\right)$, pendimethalin 30\% EC @ $1.0 \mathrm{~kg}$ a.i. ha ${ }^{-1}$ as pre-emergence application + imazethapyr 35\% WG + imazamox 35\% WG@70 g a.i. $\mathrm{ha}^{-1}$ at 2-3 leaf stage of weeds $\left(\mathrm{W}_{5}\right)$, pendimethalin $30 \% \mathrm{EC}+$ imazethapyr $2 \% \mathrm{EC}$ @ $\quad 1.0 \mathrm{~kg}$ a.i. $\mathrm{ha}^{-1}$ as pre-emergence application + imazethapyr 35\% WG + imazamox 35\% WG @ $70 \mathrm{~g}$ a.i. ha ${ }^{-1}$ at 2-3 leaf stage of weeds $\left(\mathrm{W}_{6}\right)$, pendimethalin $30 \%$ EC @ $1.0 \mathrm{~kg}$ a.i. ha ${ }^{-1}$ as pre-emergence application + imazethapyr 10\% SL @ $50 \mathrm{~g}$ a.i.ha ${ }^{-1}$ at 2-3 leaf stage of weeds $\left(\mathrm{W}_{7}\right)$, hand weeding at 20 and 40 DAS $\left(\mathrm{W}_{8}\right)$ and weedy check $\left(\mathrm{W}_{9}\right)$. Blackgram variety i.e. GBG-1 was selected for sowing.The fertilizers such as urea and SSP were used for the supply of N and $\mathrm{P}$ and the entire quantity of fertilizers applied as basal. The seed rate used for study was $25 \mathrm{~kg} \mathrm{ha}^{-1}$ with a spacing of $30 \times 10 \mathrm{~cm}$. Weed species present in the experimental plot were identified at flowering stage of crop from weedy check plot and grouped as grasses, sedges and broad leaved weeds. The data on weed dry weight were recorded with the help of a quadrate $\left(0.25 \mathrm{~m}^{-2}\right)$ at four places randomly chosen and then expressed in number per square metre and gram per square metre. The weed control efficiency was worked out on the basis of weed dry matter recorded in each treatment at 20,40,60 DAS and at harvest by using the formula suggested by Mani et al.,1973.

$\operatorname{WCE}(\%)=\frac{\mathrm{DM}_{\mathrm{C}}-\mathrm{DM}_{\mathrm{T}}}{\mathrm{DM}_{\mathrm{C}}}$

Where,

$\mathrm{DM}_{\mathrm{C}}=$ Dry matter of weeds in the unweeded check (control)

$\mathrm{DM}_{\mathrm{T}}=$ Dry matter of weeds in the treatmentimposed plot.

Values were subjected to square root transformation $(\sqrt{x+0.5})$ prior to statistical analysis to normalize their distribution. Observations on yield attributes and yield of crop were recorded and statistically analysed.

\section{Results and Discussion}

\section{Weed flora}

During the crop growth period, weed flora belonging to seven taxonomic families were observed of which four species were grasses, 
one species was sedge and six species were broad leaved weeds, of which predominant weed species observed in experimental field were Dactylactenium aegyptium, Cyperus iria, Amaranthus viridis, Digera arvensis and Parthinium hysteroporus.

Hand weeding at 20 and 40 DAS $\left(\mathrm{W}_{8}\right)$ recorded lesser weed dry weight due to reduced weed growth because of complete removal of all types of weeds like grasses, sedges and broad leaved weeds during early stages of crop growth. Among the chemical weed management practices pendimethalin $30 \% \mathrm{EC}+$ imazethapyr 2\% EC @ $1.0 \mathrm{~kg}$ a.i. $\mathrm{ha}^{-1}$ as pre-emergence application + sodium acifluorfen $16.5 \%$ SL+ clodinafop-propargyl 8\% EC@165 + $80 \mathrm{~g}$ a.i. ha ${ }^{-1}$ at 2-3 leaf stage of weeds $\left(\mathrm{W}_{4}\right)$ recorded lowest weed dry weight due to interruption of cell division, inhibition of acetolactase synthase leading to chlorosis and necrosis and then desiccated at these rates.

Similar results of higher performance of these combinations of herbicides were reported by Jha et al., (2014) and Barla et al., (2018). Higher values of weed dry weight were recorded with weedy check $\left(\mathrm{W}_{9}\right)$.

Among all the treatments, hand weeding at 20 and 40 DAS $\left(\mathrm{W}_{8}\right)$ recorded high weed control efficiency, this may be due to reduction in the weed dry weight as a result of effective weed control in this treatment, these results were in confirmatory with the findings of Patel et al., (2015), Yadav et al., (2015).

However, pendimethalin 30\% EC + imazethapyr 2\% EC @ $1.0 \mathrm{~kg}$ a.i. ha ${ }^{-1}$ as preemergence application + sodium acifluorfen $16.5 \%$ SL+ clodinafop-propargyl 8\% EC @ $165+80 \mathrm{~g}$ a.i. ha ${ }^{-1}$ at 2-3 leaf stage of weeds $\left(\mathrm{W}_{4}\right)$ performed statistically on par with hand weeding twice at 20 and 40 DAS $\left(\mathrm{W}_{8}\right)$ at all the growth stages of crop.

\section{Effect on yield attributes and yield of crop}

Yield attributes viz., number of pods plant ${ }^{-1}$, number of seeds pods ${ }^{-1}$, test weight of blackgram were significantly influenced by different weed management practices. higher values of number of pods plant ${ }^{-1}$, number of seeds pods ${ }^{-1}$, test weight were recorded with hand weeding at 20 and 40 DAS $\left(\mathrm{W}_{8}\right)$ and pendimethalin $30 \% \mathrm{EC}+$ imazethapyr $2 \% \mathrm{EC}$ @ $1.0 \mathrm{~kg} \quad$ a.i. $\mathrm{ha}^{-1}$ as pre-emergence application + sodium acifluorfen 16.5\% SL+ clodinafop-propargyl 8\% EC @ $165+80$ g a.i. ha ${ }^{-1}$ at 2-3 leaf stage of weeds $\left(\mathrm{W}_{4}\right)$, might be due to the reason that lower weed population had provided favourable environment to the crop and least crop weed competition, which resulted in higher photosynthetic accumulation rate and better translocation to the sink as compared to weedy check $\left(\mathrm{W}_{9}\right)$. Similar results were reported by Kumar et al., (2015) and Singh et al., (2016). Significantly higher seed yield and haulm yield recorded with hand weeding at 20 and 40 DAS $\left(\mathrm{W}_{8}\right)$ and pendimethalin $30 \% \mathrm{EC}+$ imazethapyr 2\% EC @ $1.0 \mathrm{~kg}$ a.i. $\mathrm{ha}^{-1}$ as pre-emergence application + sodium acifluorfen $16.5 \%$ SL + clodinafop-propargyl 8\% EC @ 165 + $80 \mathrm{~g}$ a.i. ha ${ }^{-1}$ at 2-3 leaf stage of weeds $\left(\mathrm{W}_{4}\right)$ may be due to the lower crop weed competition, weed population and weed dry weight, enabling the crop to establish and to grow vigorously resulting in better growth and development of the crop.

Further these treatments recorded higher weed control efficiency as a result of effective control of weeds especially in the critical crop weed competition period. Weedy check $\left(\mathrm{W}_{9}\right)$ recorded significantly lower seed yield and haulm yield compared to other treatments due to narrow spectrum of weed control and higher crop weed competition. Similar results of higher haulm yield with effective weed control were reported by Kumar et al., (2015) and Harithavardhini et al., (2016) (Table 1 and 2). 
Table.1 Influence of different weed management practices on weed dry weight $\left(\mathrm{g} \mathrm{m}^{-2}\right)$ and weed control efficiency (\%) in kharif blackgram

\begin{tabular}{|c|c|c|c|c|c|c|c|c|}
\hline \multirow[t]{2}{*}{ Treatment } & \multicolumn{4}{|c|}{ Weed dry weight $\left(\mathrm{g} \mathrm{m}^{-2}\right)$} & \multicolumn{4}{|c|}{ Weed Control Efficiency (\%) } \\
\hline & $\begin{array}{c}20 \\
\text { DAS }\end{array}$ & $\begin{array}{c}40 \\
\text { DAS }\end{array}$ & $\begin{array}{c}\text { 60 } \\
\text { DAS }\end{array}$ & $\begin{array}{c}\text { At } \\
\text { harvest }\end{array}$ & $\begin{array}{c}20 \\
\text { DAS }\end{array}$ & $\begin{array}{c}40 \\
\text { DAS }\end{array}$ & $\begin{array}{c}60 \\
\text { DAS }\end{array}$ & $\begin{array}{c}\text { At } \\
\text { harvest }\end{array}$ \\
\hline $\mathbf{W}_{1}$ & $\begin{array}{l}40.45 \\
(6.38)\end{array}$ & $\begin{array}{l}92.03 \\
(9.62)\end{array}$ & $\begin{array}{l}111.15 \\
(10.57)\end{array}$ & $\begin{array}{l}125.20 \\
(11.21)\end{array}$ & 33.26 & 41.92 & 48.52 & 49.66 \\
\hline $\mathbf{W}_{2}$ & $\begin{array}{l}30.60 \\
(5.58)\end{array}$ & $\begin{array}{l}74.12 \\
(8.64)\end{array}$ & $\begin{array}{l}104.86 \\
(10.26)\end{array}$ & $\begin{array}{l}118.95 \\
(10.93)\end{array}$ & 49.17 & 53.20 & 51.43 & 52.15 \\
\hline $\mathbf{W}_{3}$ & $\begin{array}{l}39.87 \\
(6.35)\end{array}$ & $\begin{array}{l}66.34 \\
(8.18)\end{array}$ & $\begin{array}{l}80.73 \\
(9.01)\end{array}$ & $\begin{array}{l}91.11 \\
(9.57)\end{array}$ & 33.82 & 58.15 & 62.61 & 63.39 \\
\hline $\mathbf{W}_{4}$ & $\begin{array}{l}28.45 \\
(5.38)\end{array}$ & $\begin{array}{l}36.02 \\
(6.04)\end{array}$ & $\begin{array}{l}55.90 \\
(7.51)\end{array}$ & $\begin{array}{l}65.21 \\
(8.11)\end{array}$ & 52.71 & 77.28 & 74.11 & 73.84 \\
\hline$W_{5}$ & $\begin{array}{l}33.54 \\
(5.83)\end{array}$ & $\begin{array}{l}55.88 \\
(7.51)\end{array}$ & $\begin{array}{l}79.18 \\
(8.93)\end{array}$ & $\begin{array}{l}85.97 \\
(9.30)\end{array}$ & 44.32 & 64.74 & 63.33 & 65.34 \\
\hline $\mathrm{W}_{6}$ & $\begin{array}{l}31.25 \\
(5.63)\end{array}$ & $\begin{array}{l}46.00 \\
(6.82)\end{array}$ & $\begin{array}{l}65.42 \\
(8.12)\end{array}$ & $\begin{array}{l}77.73 \\
(8.84)\end{array}$ & 48.05 & 70.95 & 69.70 & 68.70 \\
\hline $\mathbf{W}_{7}$ & $\begin{array}{l}31.80 \\
(5.68)\end{array}$ & $\begin{array}{l}42.39 \\
(6.55)\end{array}$ & $\begin{array}{l}61.66 \\
(7.88)\end{array}$ & $\begin{array}{l}77.44 \\
(8.83)\end{array}$ & 47.19 & 73.25 & 71.44 & 68.80 \\
\hline $\mathbf{W}_{8}$ & $\begin{array}{c}4.50 \\
(2.24)\end{array}$ & $\begin{array}{c}8.72 \\
(3.04)\end{array}$ & $\begin{array}{l}34.46 \\
(5.91)\end{array}$ & $\begin{array}{l}61.87 \\
(7.90)\end{array}$ & 92.53 & 94.50 & 84.04 & 75.07 \\
\hline$W_{9}$ & $\begin{array}{c}60.28 \\
(7.80)\end{array}$ & $\begin{array}{l}158.43 \\
(12.61)\end{array}$ & $\begin{array}{l}215.91 \\
(14.71)\end{array}$ & $\begin{array}{l}249.03 \\
(15.80)\end{array}$ & 0.00 & 0.00 & 0.00 & 0.00 \\
\hline S.Em \pm & 1.098 & 3.744 & 3.928 & 3.895 & 1.711 & 2.372 & 1.819 & 1.280 \\
\hline $\mathrm{CD}(\mathbf{P}=0.05)$ & 3.33 & 11.36 & 11.91 & 11.81 & 5.19 & 7.20 & 5.52 & 3.88 \\
\hline
\end{tabular}

Figures in parenthesis indicates square root transformed $(\sqrt{x+0.5})$ values.

Table.2 Yield attributes of blackgram as influenced by different weed management practices

\begin{tabular}{|l|c|c|c|}
\hline Treatments & Number of pods plant $^{-\mathbf{1}}$ & Number of seeds pod $^{-\mathbf{1}}$ & Test weight $^{(g)}$ \\
\hline $\mathbf{W}_{\mathbf{1}}$ & 21.80 & 5.40 & 4.27 \\
\hline $\mathbf{W}_{\mathbf{2}}$ & 24.53 & 5.73 & 4.37 \\
\hline $\mathbf{W}_{\mathbf{3}}$ & 27.13 & 5.93 & 4.40 \\
\hline $\mathbf{W}_{\mathbf{4}}$ & 44.80 & 6.13 & 4.77 \\
\hline $\mathbf{W}_{\mathbf{5}}$ & 30.27 & 5.73 & 4.50 \\
\hline $\mathbf{W}_{\mathbf{6}}$ & 33.87 & 6.00 & 4.50 \\
\hline $\mathbf{W}_{\mathbf{7}}$ & 27.93 & 6.33 & 4.60 \\
\hline $\mathbf{W}_{\mathbf{8}}$ & 45.80 & 6.40 & 4.87 \\
\hline $\mathbf{W}_{\mathbf{9}}$ & 17.93 & 5.13 & 4.20 \\
\hline $\mathbf{S . E m} \mathbf{E}$ & 2.404 & 0.281 & 0.116 \\
\hline $\mathbf{C D}(\mathbf{P}=\mathbf{0 . 0 5})$ & 7.29 & 0.85 & 0.35 \\
\hline
\end{tabular}


Table.3 Influence of different weed management on seed yield, haulm yield and harvest index

\begin{tabular}{|l|c|c|c|}
\hline \multicolumn{1}{|c|}{ Treatments } & $\begin{array}{c}\text { Seed yield } \\
\left(\mathbf{k g ~ h a}^{-\mathbf{1}} \mathbf{)}\right.\end{array}$ & $\begin{array}{c}\text { Haulm yield } \\
\left(\mathbf{k g ~ h a}^{\mathbf{- 1}} \mathbf{)}\right.\end{array}$ & $\begin{array}{c}\text { Harvest index } \\
(\mathbf{\%})\end{array}$ \\
\hline $\mathbf{W}_{\mathbf{1}}$ & 1401 & 2238 & 38.37 \\
\hline $\mathbf{W}_{\mathbf{2}}$ & 1421 & 2368 & 37.51 \\
\hline $\mathbf{W}_{\mathbf{3}}$ & 1427 & 2381 & 37.81 \\
\hline $\mathbf{W}_{\mathbf{4}}$ & 1967 & 2675 & 42.40 \\
\hline $\mathbf{W}_{\mathbf{5}}$ & 1593 & 2476 & 39.35 \\
\hline $\mathbf{W}_{\mathbf{6}}$ & 1717 & 2451 & 41.16 \\
\hline $\mathbf{W}_{\mathbf{7}}$ & 1652 & 2478 & 40.01 \\
\hline $\mathbf{W}_{\mathbf{8}}$ & 1995 & 2687 & 42.62 \\
\hline $\mathbf{W}_{\mathbf{9}}$ & 758 & 1730 & 30.47 \\
\hline $\mathbf{S . E m} \mathbf{E}$ & 65.7 & 135.6 & 1.636 \\
\hline $\mathbf{C D}(\mathbf{P}=\mathbf{0 . 0 5})$ & 199 & 411 & 4.96 \\
\hline
\end{tabular}

The higher harvest index of blackgram was registered with hand weeding at 20 and 40 DAS $\left(\mathrm{W}_{8}\right)$ (42.62) which was comparable with chemical treatments of pendimethalin $30 \% \mathrm{EC}+$ imazethapyr 2\% EC @ $1.0 \mathrm{~kg}$ a.i. $\mathrm{ha}^{-1}$ as pre-emergence application + sodium acifluorfen $16.5 \%$ SL+ clodinafop-propargyl 8\% EC @ $165+80 \mathrm{~g}$ a.i. ha ${ }^{-1}$ at 2-3 leaf stage of weeds $\left(\mathrm{W}_{4}\right)$ (42.40). Low harvest index was registered by weedy check $\left(\mathrm{W}_{9}\right)$ as compared to all other treatments. This indicated that economic yield also reduced correspondingly with biological yield. Similar results of higher harvest index with effective weed control was reported by Devaraju and Senthivel (2017).

From the above results, it can be concluded that lower weed dry weight, higher weed control efficiency, higher yield attributes and yield was obtained with hand weeding at 20 and 40 DAS $\left(\mathrm{W}_{8}\right)$ which was statistically at par with pendimethalin 30\% EC + imazethapyr 2\% EC @ $1.0 \mathrm{~kg}$ a.i. ha ${ }^{-1}$ as preemergence application + sodium acifluorfen $16.5 \%$ SL + clodinafop-propargyl 8\% EC @ $165+80 \mathrm{~g}$ a.i. ha $\mathrm{ha}^{-1}$ at 2-3 leaf stage of weeds $\left(\mathrm{W}_{4}\right)$. Over all, it can be concluded that from the present investigation, application of pendimethalin $30 \% \mathrm{EC}+$ imazethapyr $2 \% \mathrm{EC}$
@ $1.0 \mathrm{~kg}$ a.i. ha ${ }^{-1}$ as pre-emergence + sodium acifluorfen $16.5 \%$ SL + clodinafop-propargyl 8\% EC@165 + $80 \mathrm{~g}$ a.i. ha ${ }^{-1}$ at 2-3 leaf stage of weeds $\left(\mathrm{W}_{4}\right)$ was superior over rest of treatments with regard to weed control, yield and economics.

\section{References}

Barla, S., Upasani, R.R., Puran, A.N and Asha, S. 2018. Effect of plastic mulch and herbicides on weed dynamics and productivity of redgram. International Journal of Current Microbiology and Applied Sciences.7: 363-369.

Devaraju, B and Senthivel, T. 2017. Weed management in irrigated blackgram (Vigna mungo L.) in southern zone of Tamil Nadu. Journal of Advanced Studies in Agricultural, Biological and Environmental Sciences. 4: 4 29-33.

Harithavardhini, H., Jayalalitha, K., Ashoka Rani, Y., Krishnaveni, B. 2016. Efficacy of post emergence herbicides on weed control efficiency, partitioning of drymatter and yield of blackgram (Vigna mungo L. Hepper). International Journal of Food, Agriculture and Veterinary Sciences. 6 (6): 39-44. 
Jha, B.K., Chandra, R and Rohitashay, S. 2014. Influence of post emergence herbicides on weeds, nodulation and yields of soybean and soil properties. Legume Research. 37 (1): 47-54.

Kumar, D., Qureshi, A and Prem, N. 2015. Refining the weed management practices to increase the yield of urdbean (Vigna mungo L.) in northwestern India. International Journal of Applied and Pure Science and Agriculture. 1(7): 123-129.

Mani, V.S., Malla, M.L., Gautam, K.C and Bhagavan, D. 1973. Weed killing chemicals in potato cultivation. Indian Farming. 23: 17-18.

Patel, K.R., Patel, B.D., Patel, R.B., Patel, V.J and Darji, V.B. 2015. Bio-efficacy of herbicides against weeds in blackgram. Indian Journal of Weed Science. 47 (1): 78-81.

Singh, P.V., Tej Pratap, S., Singh, S.P., Kumar, A., Kavita, S., Akshita, B., Neema, B and Singh, R.P. 2016. Weed management in blackgram with pre-mix herbicides. Indian Journal of Weed Science. 48 (2): 178-181.

WWW.apagrinet.gov.in, 2016-17.

WWW.Indiastat.com, 2016-17.

Yadav, K.S., Dixit, J.P and Prajapati, B.L. 2015. Weed management effects on yield and economics of blackgram. Indian Journal of Weed Science. 47 (2): 136-138.

\section{How to cite this article:}

Susmitha, M., U. Vijaya Bhaskar Reddy, P.V. Ramesh Babu and Srinivasa Reddy, M. 2019. Efficacy of Different Herbicides on Weed dynamics and Yield Attributes in Kharif Blackgram [Vigna mungo (L.)]. Int.J.Curr.Microbiol.App.Sci. 8(06): 2026-2031. doi: https://doi.org/10.20546/ijcmas.2019.806.241 